Atmos. Chem. Phys., 18, 12765-12775, 2018

https://doi.org/10.5194/acp-18-12765-2018

(C) Author(s) 2018. This work is distributed under

the Creative Commons Attribution 4.0 License.

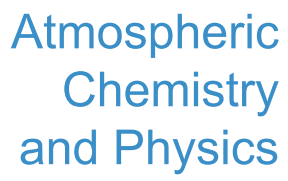

(c) (P)

\title{
Understanding nitrate formation in a world with less sulfate
}

\author{
Petros Vasilakos $^{1}$, Armistead Russell ${ }^{2}$, Rodney Weber ${ }^{3}$, and Athanasios Nenes ${ }^{1,3,4,5, \mathrm{a}}$ \\ ${ }^{1}$ School of Chemical and Biomolecular Engineering, Georgia Institute of Technology, Atlanta, Georgia 30332, USA \\ ${ }^{2}$ School of Civil and Environmental Engineering, Georgia Institute of Technology, Atlanta, Georgia 30332, USA \\ ${ }^{3}$ School of Earth and Atmospheric Sciences, Georgia Institute of Technology, Atlanta, Georgia 30332, USA \\ ${ }^{4}$ Institute of Chemical Engineering Sciences, Foundation for Research and Technology-Hellas, Patras, 26504, Greece \\ ${ }^{5}$ Institute for Environmental Research and Sustainable Development, \\ National Observatory of Athens, Palea Penteli, 15236, Greece \\ ${ }^{a}$ currently at: School of Architecture, Civil \& Environmental Engineering, \\ École polytechnique fédérale de Lausanne, 1015 Lausanne, Switzerland
}

Correspondence: Athanasios Nenes (athanasios.nenes@epfl.ch)

Received: 27 April 2018 - Discussion started: 8 May 2018

Revised: 4 July 2018 - Accepted: 20 July 2018 - Published: 5 September 2018

\begin{abstract}
SO}_{2}$ emission controls, combined with modestly increasing ammonia, have been thought to generate aerosol with significantly reduced acidity for cases in which sulfate is partially substituted by nitrate. However, neither expectation agrees with decadal observations in the southeastern USA, suggesting that a fundamentally different response of aerosol $\mathrm{pH}$ to emissions changes is occurring. We postulate that this nitrate substitution paradox arises from a positive bias in aerosol $\mathrm{pH}$ in model simulations. This bias can elevate $\mathrm{pH}$ to a level at which nitrate partitioning is readily promoted, leading to behavior consistent with nitrate substitution. CMAQ simulations are used to investigate this hypothesis; modeled $\mathrm{PM}_{2.5} \mathrm{pH}$ using 2001 emissions compare favorably with $\mathrm{pH}$ inferred from observed species concentrations. Using 2011 emissions, however, leads to simulated $\mathrm{pH}$ increases of one unit, which is inconsistent with observations from that year. Nonvolatile cations $\left(\mathrm{K}^{+}, \mathrm{Na}^{+}, \mathrm{Ca}^{+2}\right.$, and $\mathrm{Mg}^{+2}$ ) in the fine mode are found to be responsible for the erroneous predicted increase in aerosol $\mathrm{pH}$ of about 1 unit on average over the USA. Such an increase can induce a nitrate bias of $1-2 \mu \mathrm{g} \mathrm{m}^{-3}$, which may further increase in future projections, reaffirming an otherwise incorrect expectation of a significant nitrate substitution. Evaluation of predicted aerosol $\mathrm{pH}$ against thermodynamic analysis of observations is therefore a critically important, but overlooked, aspect of model evaluation for a robust emissions policy.
\end{abstract}

\section{Introduction}

Aerosol acidity is a driver of many important atmospheric processes (Guo et al., 2015; Weber et al., 2016), catalyzing the conversion of isoprene oxidation products to form secondary organic aerosol (SOA) (Xu et al., 2015; Pye et al., 2013; Surratt et al., 2010; Eddingsaas et al., 2010) and driving the semivolatile partitioning of key aerosol species (Guo et al., 2015; Weber et al., 2016). High acidity can also lead to the solubilization of iron, copper and other trace metals in aerosol, which may serve as nutrients for ecosystems (Meskhidze et al., 2003), but also prove toxic for humans (Ghio et al., 2012; Fang et al., 2017). Significant reductions in primary pollutant emissions over the last decades have greatly improved air quality in the developed world and are also thought to fundamentally affect aerosol acidity. $\mathrm{SO}_{2}$, an important aerosol precursor and a major driver of its acidity, has seen decreases of about $6 \% \mathrm{yr}^{-1}$ over the 2001-2011 period alone in the USA, with a continued anticipated downward trend (Pinder et al., 2007, 2008). Emissions of $\mathrm{NO}_{x}$ and the resulting acidic $\mathrm{HNO}_{3}$, are also declining. In contrast, ammonia, the primary alkaline fine-mode aerosol precursor, was either constant or increasing during this period (Pinder et al., 2007, 2008; Heald et al., 2012), owing to intensified agricultural activity and livestock farming from the demands of population growth. These trends have created the expectation that the aerosol has and will become increasingly less acidic (West et al., 1999; Pinder et al., 2007, 2008; Heald 
et al., 2012; Tsimpidi et al., 2007; Saylor et al., 2015), with ammonium sulfate being replaced, at least in part, by ammonium nitrate (West et al., 1999; Bauer et al., 2007; Bellouin et al., 2011; Li et al., 2014; Goto et al., 2016).

The concept of nitrate substitution of sulfate has largely been based on the notion that nitrate is volatile when the aerosol is acidic, and in turn aerosol is acidic when insufficient amounts of total ammonia (i.e., gas+aerosol) or dust nonvolatile cations (NVCs) exist to neutralize aerosol sulfate. Based on this conceptual model, aerosol ionic molar ratios have largely been used as proxies of aerosol acidity $(\mathrm{pH})$, so that when the aerosol ammonium to sulfate molar ratio approaches 2 (the composition of ammonium sulfate), aerosol is assumed neutral and only then can nitrate aerosol form (Fisher et al., 2011; Hennigan et al., 2015; Wang et al., 2016; Silvern et al., 2017). Modeling studies have corroborated this view, predicting that nitrate substitution may be prevalent in the future, including in the southeastern USA (SE USA) (Heald et al., 2012; Bauer et al., 2007; Bellouin et al., 2011; Li et al., 2014; Goto et al., 2016; Vayenas et al., 2005; Karydis et al., 2016). A more careful analysis, however (Guo et al., 2015, 2016; Weber et al., 2016; Hennigan et al., 2015), reveals that this conceptual model of aerosol acidity and conditions for nitrate substitution fails; thermodynamic analysis of SE US aerosol observations instead show that fine-mode aerosol remains strongly acidic, despite a $70 \%$ reduction in sulfates and more than a sufficient amount of total ammonia to neutralize it. The strong acidity is maintained by the large difference in volatility between sulfate and ammonia (Guo et al., 2015; Weber et al., 2016), so large changes in total ammonia concentrations are required for a notable change in aerosol acidity, of about 1 order of magnitude increase in $\mathrm{NH}_{3}$ concentration per unit increase in aerosol $\mathrm{pH}$ (Guo et al., 2015, 2017c). However, ammonia gas deposits relatively rapidly, limiting its build up except in high-emission regions. Throughout the decade, the levels of aerosol nitrate have remained relatively constant throughout the USA (Guo et al., 2015; Weber et al., 2016; Pye et al., 2009). The persistent strong aerosol acidity in turn explains why nitrate aerosol has not considerably increased over the last decades and is unlikely to appear in the immediate future in the SE USA. These findings constitute a paradox, as the same thermodynamic models (e.g., ISORROPIA-II, Fountoukis and Nenes, 2007) used to demonstrate the aerosol tendency for strong acidity in the SE USA (Guo et al., 2015; Weber et al., 2016) using ambient data are also used in 3-D modeling studies (Pye et al., 2009; Heald et al., 2012) for the region that predicts nitrate substitution as a possible aerosol response.

Reconciling the nitrate substitution paradox requires a careful examination of aerosol thermodynamics and the conditions under which nitrate partitioning to the aerosol is favored. Meskhidze et al. (2003) and later Guo et al. (2016) showed that, for aerosol nitrate formation to occur, aerosol $\mathrm{pH}$ needs to exceed a certain characteristic value (depending on the temperature and the amount of liquid water it ranges between a pH of 1.5 and 3; Guo et al., 2017b). If aerosol $\mathrm{pH}$ is therefore high enough (typically above a $\mathrm{pH}$ of 2.5 to 3 ), a behavior consistent with nitrate substitution emerges, because any inorganic nitrate forming from $\mathrm{NO}_{x}$ chemistry mostly resides in the aerosol phase. When $\mathrm{pH}$ is low enough (typically below 1.5 to 2), nitrate remains exclusively in the gas phase (as $\left.\mathrm{HNO}_{3}\right)$, regardless of the amount produced, and nitrate substitution is not observed. Between these high and low $\mathrm{pH}$ values, a sensitivity window emerges (of typically $1-1.5 \mathrm{pH}$ units), at which partitioning shifts from nitrate being predominantly found as a gas to being mostly found as an aerosol. Therefore, if a model is for any reason biased in its prediction of aerosol $\mathrm{pH}$, it may be preconditioned towards nitrate prediction biases. The sensitivity to $\mathrm{pH}$ biases is strongest when the aerosol lies in the $\mathrm{pH}$ sensitivity window, which is often the case for atmospheric aerosol (Guo et al., 2015, 2016, 2017b; Bougiatioti et al., 2016). When below this $\mathrm{pH}$ sensitivity window, aerosol nitrate is almost nonexistent and relatively insensitive to emissions (and $\mathrm{pH}$ biases); when above the window, almost all nitrate resides in the aerosol phase and directly responds to $\mathrm{NO}_{x}$ emission controls.

If aerosols were composed only of nonvolatile sulfate, semivolatile nitrate and ammonium, prediction biases in $\mathrm{pH}$ could result only from errors in $\mathrm{RH}$, and large errors (e.g., order of magnitude) of $\mathrm{NH}_{3}, \mathrm{NO}_{x}$ and $\mathrm{SO}_{2}$ because $\mathrm{pH}$ is relatively insensitive to changes in these aerosol precursors (Hennigan et al., 2015; Guo et al., 2017c). Acidity, however, can also be modulated by other soluble inorganic cations from sea salt and mineral dust, such as $\mathrm{K}^{+}, \mathrm{Na}^{+}, \mathrm{Ca}^{+2}$ and $\mathrm{Mg}^{+2}$. The low volatility of these cations allows them to preferentially neutralize sulfates over $\mathrm{NH}_{3}$, and, even in small amounts, elevate particle $\mathrm{pH}$ to levels that can promote the partitioning of nitrates to the aerosol phase (Fountoukis and Nenes, 2007; Guo et al., 2017a). NVCs tend to reside in the coarse-mode aerosol, with a fraction found in smaller particles, while sulfate tends to reside in the fine mode (e.g., West et al., 1999; Vayenas et al., 2005; Guo et al., 2015); the degree to which NVCs can affect fine-mode $\mathrm{pH}$ therefore lies in the degree at which the two types of species mix across different particle sizes. Potential interactions between inorganics and organics can also affect aerosol acidity. However, recent studies driving thermodynamic models utilizing water associated with organics find only minimal differences in $\mathrm{pH}$ predictions (Guo et al., 2015; Bougiatioti et al., 2016; M. Liu et al., 2017; Pye et al., 2018; Song et al., 2018). In the presence of very high NVCs (for example in sea-spray aerosol), where the aerosol has much higher $\mathrm{pH}$, the $\mathrm{pH}$ can approach the pKa of organic acids, leading to conditions in which their dissociation can contribute to aerosol acidity (Laskin et al., 2012).

Although aerosol models are evaluated in terms of their ability to predict the concentration of aerosol species (including across size), no studies to date focus on their ability to predict aerosol $\mathrm{pH}$ across size, even though it is known to 
potentially vary up to 6 units (Fang et al., 2017; Bougiatioti et al., 2016; Li et al., 2017). Evaluation of models in this context is challenging, since there is no established data set of aerosol acidity - although that is rapidly changing, with $\mathrm{pH}$ estimates derived from a combination of observations and models (e.g., Guo et al., 2015, 2017b, c; Bougiatioti et al., 2016; Y. Liu et al., 2017; Song et al., 2018). Furthermore, given that most of this $\mathrm{pH}$ variability occurs in the $\mathrm{PM}_{1}$ to $\mathrm{PM}_{2.5}$ range (Fang et al., 2017), it is quite likely that model assumptions on how aerosol species interact within a mode (degree of internal mixture) may lead to $\mathrm{pH}$ prediction biases that drive model behavior, especially for particles in the $1-2.5 \mu \mathrm{m}$ range.

The aim of this study is to address the underlying reasons for the nitrate substitution paradox, and in the process, provide a conceptual framework for quantifying and understanding the importance of aerosol $\mathrm{pH}$ biases. The guiding hypothesis of this work is that aerosol $\mathrm{pH}$ prediction bias fundamentally changes predicted aerosol behavior and is the underlying cause of the paradox. The approach is demonstrated with the Community Multiscale Air Quality (CMAQ) model (Byun and Schere, 2006) and is based on predictions of $\mathrm{pH}$ over the 2001-2011 period in the southeastern and eastern USA, which is the region in which aerosol $\mathrm{pH}$ trends are constrained by observations. The role of internally mixed nonvolatile cations in $\mathrm{PM}_{2.5}$ as a source of the $\mathrm{pH}$ bias is then assessed.

\section{Methods}

\section{Predicting aerosol pH and composition}

CMAQ is a three-dimensional, Eulerian, atmospheric chemistry and transport model, which simulates the processes that atmospherically relevant compounds undergo, such as emission, diffusion, chemical reactions and deposition (Byun and Schere, 2006). CMAQ version 5.0.2 was used in this study, and simulations were carried out using a $36 \mathrm{~km}$ horizontal resolution grid, with 13 vertical layers, over the continental USA (CONUS) for the entirety of 2001 and 2011. Meteorological data were obtained offline from the Weather Research Forecasting (WRF) model. The same meteorology was used for the 2 years to eliminate the effect of differences due to temperature and relative humidity on $\mathrm{pH}$ predictions. Modelready emissions for 2011 were obtained using the National Emissions Inventory 2011 inventory (NEI 2011) for the Carbon Bond 05 (CB05) chemical mechanism. To estimate the 2001 emissions, the 2011 emissions for $\mathrm{SO}_{2}, \mathrm{NO}_{x}, \mathrm{NH}_{3}, \mathrm{CO}$, VOCs and primary PM from anthropogenic sources were scaled on a per-species basis using the Air Pollutant Emissions Trends Data (2017); emissions for other species were kept constant. Specifically, anthropogenic $\mathrm{CO}, \mathrm{NO}_{x}$, primary $\mathrm{PM}$ and $\mathrm{SO}_{2}$ emissions were increased by $44 \%, 45 \%, 15 \%$ and $246 \%$ respectively, while $\mathrm{VOC}$ and $\mathrm{NH}_{3}$ emissions were reduced by $6 \%$ and $14 \%$. Emissions of biogenic species were calculated online using the Biogenic Emission Inventory System (BEIS).

The aerosol thermodynamic model ISORROPIA-II (Fountoukis and Nenes, 2007) was used online in CMAQ to drive the semivolatile partitioning of inorganic species and offline to analyze the predicted $\mathrm{PM}_{2.5} \mathrm{pH}$, nitrate partitioning tendency and sensitivities thereof to nonvolatile cations. It should be noted that ISORROPIA and CMAQ only account for thermodynamic interactions between inorganic species and do not treat organics. Offline calculations were conducted using the hourly gas and particle phase concentration output from CMAQ for the 2001 and 2011 simulations, which includes NVCs, and using them as input to ISORROPIA-II (subversion 2.3 - dated 2012). The thermodynamic calculations online and offline were carried out in the forward mode, meaning that the temperature, relative humidity, as well as all aerosol and gas phase concentrations were known and used as input, while at the same time it was assumed that the aerosol is in a metastable state, for which only one aqueous phase is allowed to exist (Fountoukis and Nenes, 2007). This assumption is not always necessarily true, especially under conditions of low relative humidity $(\mathrm{RH}<30 \%)$ at which the aerosol can crystalize or exist in glassy, amorphous state (in this case thermodynamic equilibrium is not reached), observational data of liquid water content shows that it is most often a valid assumption (Guo et al., 2015; Bougiatioti et al., 2016), and other studies suggest that the phase state may not strongly affect predicted $\mathrm{pH}$ (Song et al., 2018). We run the model under a variety of conditions to determine the impact of NVCs from dust and sea salt $(\mathrm{Ca}, \mathrm{Mg}, \mathrm{K}, \mathrm{Na})$ on $\mathrm{pH}$ and its seasonal variability, as well as the effect of $\mathrm{pH}$ and temperature on nitrate partitioning.

\section{Results and discussion}

\subsection{Predicted sulfate, ammonium and nitrate}

For the main inorganic aerosol species $\left(\mathrm{SO}_{4}^{-2}, \mathrm{NO}_{3}^{-}\right.$and $\mathrm{NH}_{4}^{+}$), CMAQ captures the observed trends, as seen in the literature (Park et al., 2006; Hand et al., 2012; Blanchard et al., 2013a, b; Kim et al., 2015; Saylor et al., 2015) over the CONUS throughout decade (Fig. S1 in the Supplement). As expected, sulfate over the entire USA drops significantly between 2001 and $2011(\sim 30 \%)$, with major decreases in the eastern USA $\left(\sim 2 \mu \mathrm{g} \mathrm{m}^{-3}\right)$. Areas impacted the most by these reductions are places of significant industrial activity or coalfired electricity generating units (EGUs), such as the Ohio River Valley, Baton Rouge in Louisiana and South Carolina. Ammonium levels only experience small reductions, which are consistent with a buffered response to the decrease in sulfate levels, and minimal changes in emissions. Local reductions $(\sim 20 \%)$ in ammonia are seen over North Carolina and 

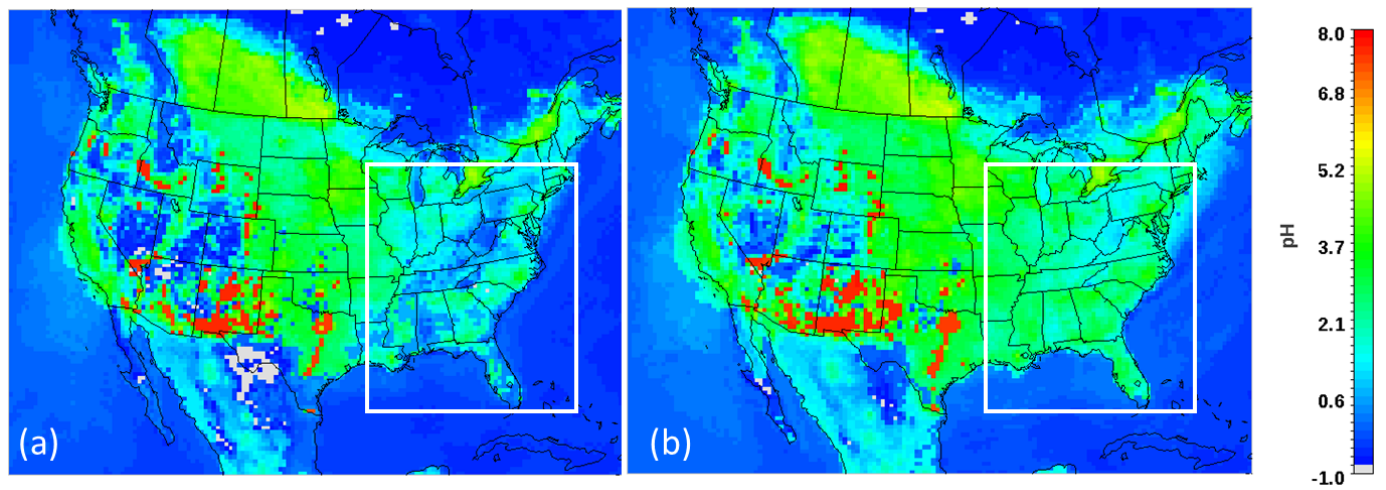

Figure 1. Annual averaged $\mathrm{PM}_{2.5} \mathrm{pH}$ over CONUS for (a) 2001 and (b) 2011, calculated offline using ISORROPIA II and the annual averaged CMAQ concentration fields. The white outline specifies the eastern US domain used for further analysis.

Louisiana. Aerosol nitrate concentrations remain constant on average over the domain, with small increases over the eastern USA. The highest levels of ammonium are observed in areas with significant livestock, such as North Carolina and the Midwest; sulfate concentrations are the highest around the Ohio River Valley due to $\mathrm{SO}_{x}$ emissions and so is nitrate due to significant $\mathrm{NO}_{x}$ and ammonia emissions.

\subsection{Predicted annual and seasonal $\mathrm{pH}$}

Figure 1 depicts the annual average $\mathrm{pH}$ fields over the USA for 2001 and 2011, calculated using the annual average $\mathrm{PM}_{2.5}$ concentrations, with the study domain of the outlined eastern USA. Simulations show that there are noticeable differences between the two years, localized mainly in desert regions along the US-Mexico border, southern Texas and the eastern USA. The sulfate reductions in the eastern USA appear to have a major impact on model results, leading to significant increases in aerosol $\mathrm{pH}$ in the area. For 2001, the average yearly $\mathrm{pH}$ for the eastern USA is 1.6 , consistent with recent literature and observations from the WINTER campaign (Guo et al., 2015, 2016; Weber et al., 2016) (Fig. 1a). For 2011, however, predicted $\mathrm{pH}$ increases to about 2.5 - almost a unit higher (Fig. 1b).

Seasonal $\mathrm{pH}$ trends are also positive over the eastern USA, with the summertime (Fig. S2f) experiencing stronger increases than in the winter (Fig. S2c), being 0.5-1.5 for winter and 0.5-2 for summer. Much of the seasonal variability is driven by changes in temperature and relative humidity: increased relative humidity $(\mathrm{RH})$ leads to less acidic aerosol, since liquid water content and $\mathrm{pH}$ are inversely related (Guo et al., 2015, 2016), while increased temperatures promote low $\mathrm{RH}$ nitrate partitioning and therefore more acidic aerosol. The desert areas of the western USA, southern Texas, Florida, SW Alabama and Mississippi are the most sensitive in the wintertime (Fig. S2a, b), while the central USA is mostly unaffected. During the summer, the entire central USA is much more strongly impacted, while the wintertime sensitive areas exhibit only minor $\mathrm{pH}$ increases (Fig. S2d, e).

\subsection{Model evaluation of $\mathbf{p H}$}

Model results for both simulation years were compared to thermodynamic analysis of measurements from three urban sites in Atlanta, Georgia (Jefferson Street, JST; Georgia Tech, GT; Atlanta Road-Side, RS) and two rural (Yorkville, Georgia - YRK; and Centerville, Alabama - CTR) SEARCH network sites. Measurements for the urban sites and the YRK site were taken between May and December 2012 for the SCAPE study, while measurements from the CTR site were for the SOAS campaign period (1 June to 15 July 2013) (Guo et al., 2015; Xu et al., 2015). The three urban sites are contained within the same CMAQ grid cell. All urban sites (Fig. 2a, b, c, d) exhibit an early morning/late night pH maximum and an afternoon minimum throughout the year (Guo et al., 2015). This a combination of two factors: RH being highest during the early morning/late night, which increases water uptake and hence decreases acidity (Guo et al., 2015) (Fig. S3), and the presence of crustal elements in significant quantities during that time (Fig. S4). The model pH closely tracks the diurnal profile of predicted cations (Fig. S4), indicating that they have an important impact on predicted $\mathrm{pH}$, which, however, is not seen in the measurements (Fig. 2), since they make up a much smaller percentage of observed $\mathrm{PM}_{2.5}$. Despite the presence of NVCs, the $\mathrm{pH}$ remains low for both simulation years but it tends to be higher in 2011, because of sulfate levels that are approximately half of those in 2001 across all sites, leading to the increased relative effect of NVCs (Weber et al., 2016). Removal of all NVCs from the thermodynamic calculations (Fig. S5), significantly reduces the $\mathrm{pH}$ differences between 2001 and 2011 while removing some of the increased variability introduced by NVCs. At the same time, a negative bias is introduced to the simulated $\mathrm{pH}$, which is more prominent for the urban sites, even after the sulfate reductions. 
Urban sites
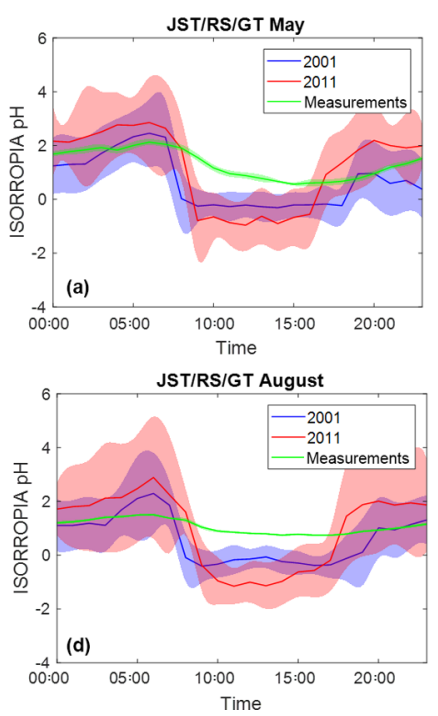
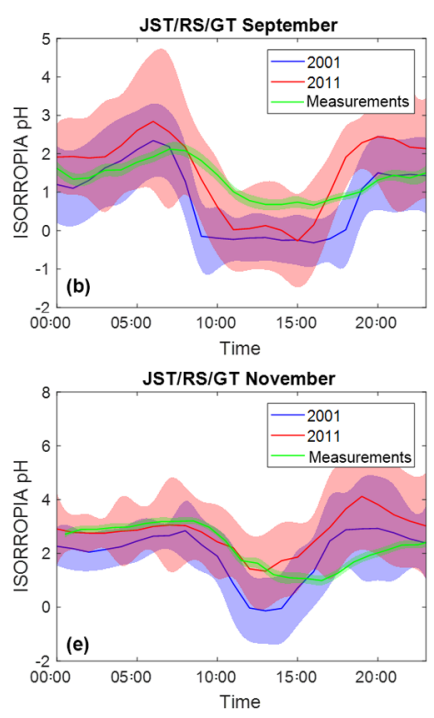

Rural sites
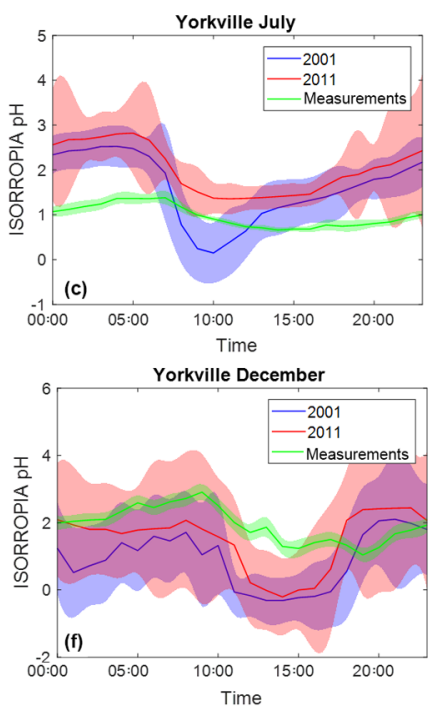

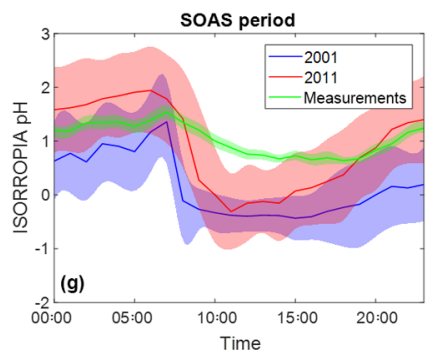

Figure 2. pH diurnal profiles for May (a), August (b), September (c) and November (d) at JST/RS/GT, July (e) and December (f) at YRK and for the SOAS campaign period (g). Blue and red lines are the offline ISORROPIA simulated pH using CMAQ concentrations for 2001 and 2011 respectively, while the shaded areas are 1 model standard deviation. The green line represents the $\mathrm{pH}$ calculated through the thermodynamic analysis of the measurements (found in Guo et al., 2015) and the shaded area is the standard error.

The increase in $\mathrm{pH}$ is not proportional to the reduction in sulfate, since aerosol responds nonlinearly to such reductions through the volatilization of ammonia (Weber et al., 2016). Depending on location, sulfate reductions range from $38 \%$ to $55 \%$, while the corresponding $\mathrm{pH}$ increase is much lower, pointing to the fact that cations, although small in amount, tend to have a disproportionately strong impact on acidity. For the SOAS campaign period (Fig. $2 \mathrm{~g}$ ), $\mathrm{pH}$ is underestimated, especially for 2001. The biases follow the pattern of NVCs present, by being negatively biased until noon and positively biased for the rest of the day (Figs. 2 and S4). The bias is particularly evident in the early morning hours, when NVC concentrations reach a maximum (Fig. S4). For the YRK site (Fig. 2b, e), pH is underestimated overall during the winter and overestimated during the summer. Similarly to the urban sites, the predicted RH agrees well with the measurements (Fig. S3), albeit with a positive afternoon bias during the summer. The diurnal profile of $\mathrm{pH}$ closely tracks the one of cations, further suggesting they may be directly related to the bias.

When evaluating the predicted $\mathrm{pH}$ trend for CTR, the model results exhibit a clear, increasing trend of $0.6 \mathrm{pH}$ units per decade (Fig. 3). This trend is inconsistent with recent thermodynamic analysis of observations, suggesting a slight decrease in $\mathrm{pH}$ over the same time period for the SE USA (Guo et al., 2015, 2016; Weber et al., 2016). If this bias in predicted $\mathrm{pH}$ trend continues, it can have profound implications for future regulatory modeling, since the increased $\mathrm{pH}$ can lead to elevated levels of model nitrate, reproducing nitrate substitution (Bauer et al., 2007; Bellouin et al., 2011; Li et al., 2014; Goto et al., 2016). Possible reasons behind this $\mathrm{pH}$ bias could be overestimated ammonia emissions, underestimated sulfate or the presence of NVCs in $\mathrm{PM}_{2.5}$. The first two possibilities are unlikely, given the agreement of predicted ammonium and sulfate with previous studies (Park et al., 2006; Hand et al., 2012; Blanchard et al., 2013a, b; Kim et al., 2015; Saylor et al., 2015), and the relative insensitivity of $\mathrm{pH}$ to ammonia and sulfate (Weber et al., 2016; Silvern et al., 2017). However, NVCs, if inappropriately distributed in $\mathrm{PM}_{2.5}$, can exert significant biases on $\mathrm{pH}$ (Meskhidze et al., 2003; Karydis et al., 2016; Guo et al., 2017b). Indeed, offline calculations of aerosol $\mathrm{pH}$ excluding the influence of NVCs mitigates most of the predicted positive trend of $0.6 \mathrm{pH}$ units per decade when all the aerosol species are considered (Fig. 3), while also reducing the standard error. The remaining bias may arise from errors in model $\mathrm{RH}$, given that it controls water uptake and drives much of the diurnal variability in $\mathrm{pH}$ (Guo et al., 2015). Usage of observed (instead of predicted) RH in the thermodynamic calculations did not impact the predicted $\mathrm{pH}$ more than 0.1 units (Fig. S6). A more thorough evaluation of the remainder of the $\mathrm{pH}$ bias, as well as the impact of NVCs when included in appropriate quantities, requires a far more extensive analysis of the emissions profiles - especially regarding its diurnal variability - and observational data set than the one available for this study (Henneman et al., 2017; Guo et al., 2017c).

The $\mathrm{pH}$ bias becomes negative for most of the CMAQ eastern USA when removing all NVCs from the calculations (Fig. S5). This, combined with the considerable model skill for sulfate, nitrate and ammonium when compared to the lit- 


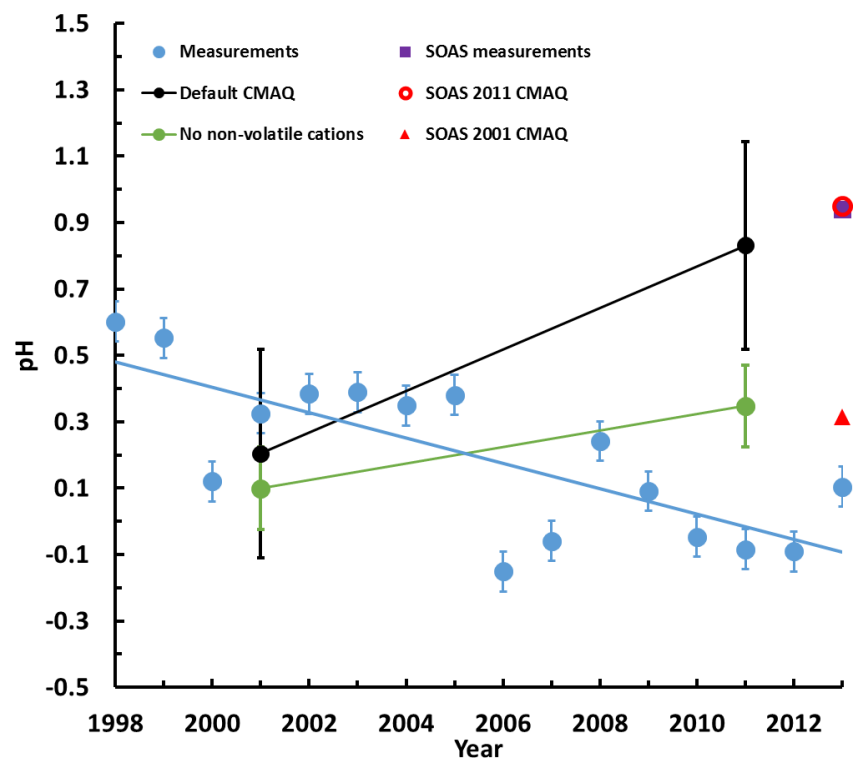

Figure 3. Decadal $\mathrm{pH}$ trends from the thermodynamic analysis of the measurements from Weber et al. (2016) (blue line), default CMAQ (black line) and CMAQ results at the Centreville grid cell without crustal elements (green line). Also shown is the $\mathrm{pH}$ for the SOAS campaign and the CMAQ-predicted $\mathrm{pH}$ for 1 June-15 July 2001 and 2011. CMAQ exhibits a clear positive trend, with $\mathrm{pH}$ increasing throughout the decade, both due to sulfate reductions and the increasingly important role of NVCs. Standard error is also plotted for all data points.

erature (Henneman et al., 2017), implies that $\mathrm{pH}$ biases are not related to errors in the major inorganic ions or biases in meteorological parameters (humidity and temperature), but rather in the NVCs, which are minor contributors to $\mathrm{PM}_{2.5}$ and hence poorly constrained. For the SEARCH sites, NVCs comprise $5 \%$ to $10 \%$ of the total inorganic $\mathrm{PM}_{2.5}$ (Guo et al., 2015), which is significantly less than the model-predicted values that are a factor of 4 higher than the measurements. The most important result, therefore, is that NVCs are a considerable source of $\mathrm{pH}$ prediction uncertainty when not accounted for correctly (Supplement: The role of NVCs in $\left.\mathrm{PM}_{2.5} \mathrm{pH}\right)$. It should be noted that, for the summertime at the CTR location, the ammonium and sulfate values are biased low in CMAQ by a factor of 3 using the Weber et al. (2016) data. These biases, however, are consistent with literature and typical of CTMs (Henneman et al., 2017).

The SEARCH sites have been thoroughly studied in the previous literature (Guo et al, 2015, 2017a; Xu et al., 2015; Weber et al., 2016) and given the high concentrations of organic mass observed throughout the year, they present an excellent case study for the potential impact of organics on $\mathrm{pH}$. Recent studies indicate that organic aerosol can have a secondary, but still quantifiable impact on aerosol $\mathrm{pH}$, especially when allowed to interact with inorganics (Pye et al., 2018). Most 3-D models do not account for potential, nonideal inter-

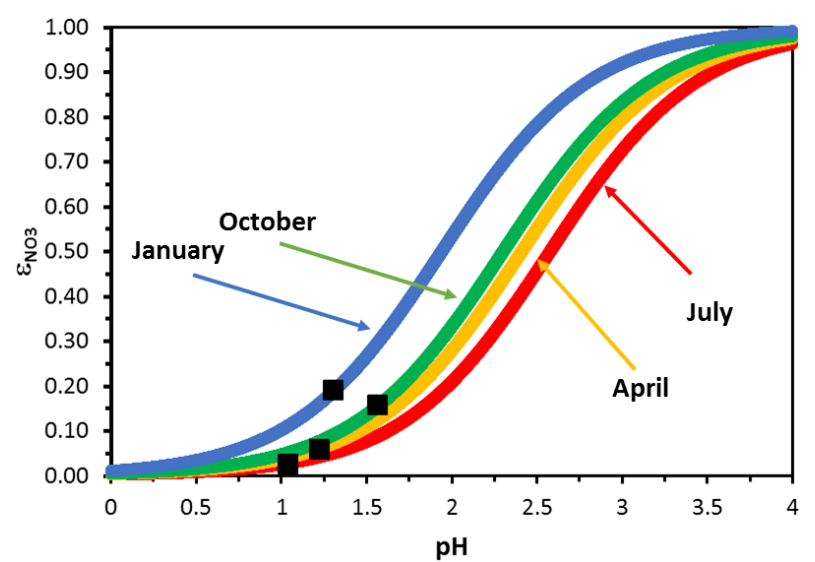

Figure 4. CMAQ-derived nitrate partitioning ratio for the eastern USA and select months of 2001. The black squares denote the average $\mathrm{pH}$ values for each month. Note the insensitivity of nitrate partitioning to $\mathrm{pH}$ biases in the summer for $\mathrm{pH}$ values of less than 1 $\left(\frac{\partial \varepsilon_{\mathrm{NO}_{3}}}{\partial \mathrm{pH}} \sim 0\right)$, which is not the case for colder months.

actions between the two, in addition to not including organics in thermodynamic calculations, which, if the above statement is true, can lead to significant predictive $\mathrm{pH}$ errors. To investigate the role of organics on $\mathrm{pH}$ we used the E-AIM model (Wexler and Clegg, 2002; Friese and Ebel, 2010; Clegg et al., 1992) (http://www.aim.env.uea.ac.uk/aim/aim.php, last access: 1 April 2018) on our model results for the SEARCH sites to calculate partitioning with the considered organicinorganic interactions. We tested a variety of organic compounds under different scenarios to determine the potential of organics to influence $\mathrm{pH}$ (see Supplement: Organic acids and $\mathrm{pH}$ ).

We find that the addition of organic compounds to the model did not have a significant impact on acidity $(\leq 2 \% \mathrm{pH}$ deviation from the baseline value) compared to the baseline run, apart from the cases in which RH was higher than $80 \%$ and the mole fraction of organic acids in the aqueous phase is greater than $25 \%$ (Supplement: Organic acids and $\mathrm{pH}$ ). We conclude that the maximum impact of organics on aerosol $\mathrm{pH}$ can likely result from the effects of liquid-liquid phase separation (Pye et al., 2018) but are of insufficient magnitude to sustain a positive aerosol $\mathrm{pH}$ trend as observed in our base case simulation.

\subsection{The impact of $\mathrm{pH}$ biases on nitrate partitioning and sulfate-nitrate substitution}

To understand the importance of $\mathrm{pH}$ biases on nitrate partitioning and the potential for predicting a behavior consistent with nitrate substitution, we express the CMAQ output in each grid cell in terms of the nitrate partitioning ratio, $\varepsilon_{\mathrm{NO}_{3}}=\frac{\left[\mathrm{NO}_{3}^{-}\right]}{\left[\mathrm{HNO}_{3}\right]+\left[\mathrm{NO}_{3}^{-}\right]}$. It can be shown that $\varepsilon_{\mathrm{NO}_{3}}$ follows a simple sigmoidal curve (Meskhidze et al., 2003; Guo et al., 

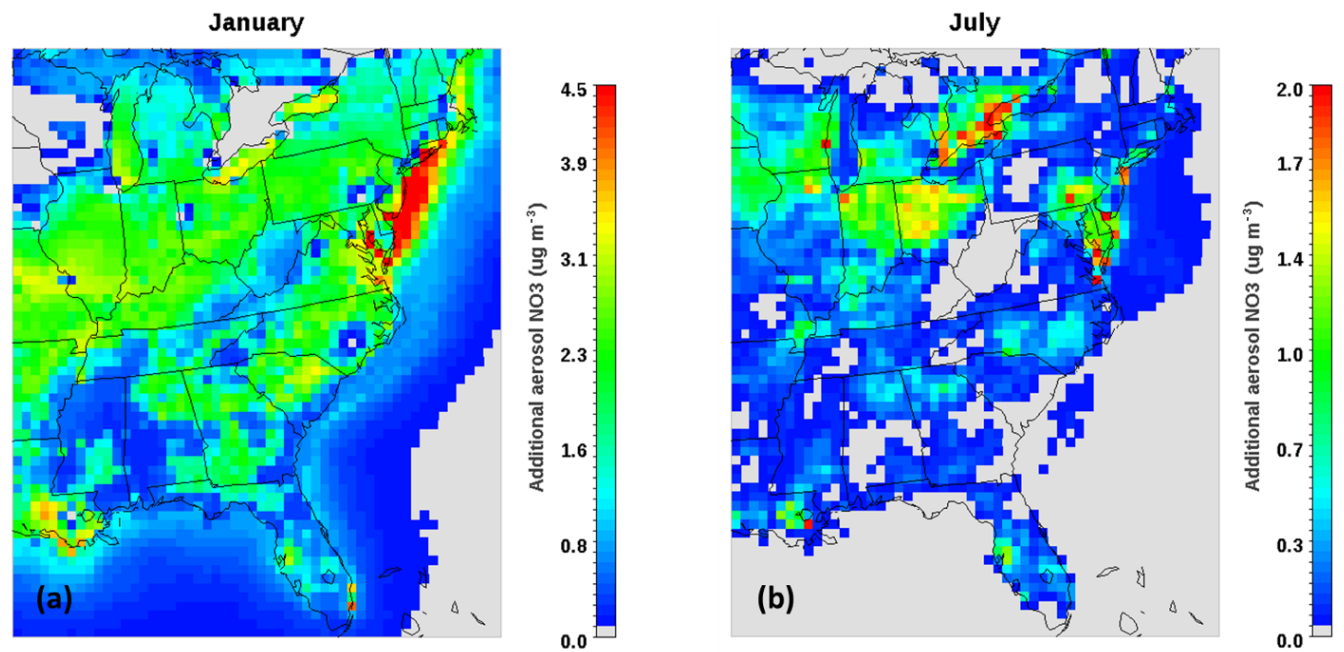

Figure 5. Increase in aerosol nitrate corresponding to a one-unit positive change in $\mathrm{pH}$ for (a) January and (b) July. Emissions for 2011 are assumed, but to account for $\mathrm{pH}$ prediction biases from NVCs, they are removed from the thermodynamic calculations. Plots are on different scales due to the large differences in predicted nitrate increases.

2016), $\varepsilon_{\mathrm{NO}_{3}}=1-\frac{\left[\mathrm{H}^{+}\right]}{\left[\mathrm{H}^{+}\right]+L \cdot T \cdot \Psi}$, where $L$ is the liquid water content, $T$ is ambient temperature, $\left[\mathrm{H}^{+}\right]$is the concentration of $\mathrm{H}^{+}$in the aerosol aqueous phase, and $\Psi=\frac{R \cdot\left[H_{\left.\mathrm{NO}_{3}\right]}\right]}{1000 \cdot P_{0}}$ is a fitting parameter that depends on the universal gas constant $(R)$, the effective Henry's law constant for nitric acid in the aerosol aqueous phase $\left(\mathrm{H}_{\mathrm{NO}_{3}}\right)$ and the standard pressure $\left(P_{0}\right)$. Depending on the value of $\mathrm{pH}$, nitrate partitioning in CMAQ can either be insensitive $\left(\frac{\partial \varepsilon_{\mathrm{NO}_{3}}}{\partial \mathrm{pH}} \sim 0\right)$ or sensitive $\left(\frac{\partial \varepsilon_{\mathrm{NO}_{3}}}{\partial \mathrm{pH}} \sim 0.5\right)$ to $\mathrm{pH}$ biases, depending on the month of the year considered (Fig. 4). We generally find that nitrate partitioning is insensitive $\left(\frac{\partial \varepsilon_{\mathrm{NO}_{3}}}{\partial \mathrm{pH}} \sim 0\right)$ and heavily shifted to the gas phase $\left(\varepsilon_{\mathrm{NO}_{3}} \sim 0\right)$ during the summer and spring (Fig. 4), while it becomes quite sensitive to $\mathrm{pH}$ errors $\left(\frac{\partial \varepsilon_{\mathrm{NO}_{3}}}{\partial \mathrm{pH}} \sim 0.5\right)$ in the winter and fall. For the latter case, this means that small $\mathrm{pH}$ perturbations in either direction can strongly affect the amount of nitrate that partitions in the aerosol phase; if the weather is sufficiently cold and $\mathrm{NO}_{x}$ emissions and $\mathrm{pH}$ predictions are biased sufficiently high, $\varepsilon_{\mathrm{NO}_{3}} \sim 1$, meaning that all nitrates are partitioned to the aerosol phase and the emergence of nitrate substitution behavior.

To exemplify the above, we determine the amount of excess nitrate from $\mathrm{pH}$ prediction biases as follows. Perturbing the acidity by $\Delta \mathrm{pH}$ from the monthly mean value along the $\varepsilon_{\mathrm{NO}_{3}}$ curves (Fig. 4) gives the corresponding change in the partitioning ratio $\left(\Delta \varepsilon_{\mathrm{NO}_{3}}\right)$. Multiplying $\Delta \varepsilon_{\mathrm{NO}_{3}}$ with the total nitrate $\left(\mathrm{HNO}_{3(\mathrm{~g})}+\mathrm{NO}_{3}\right)$ predicted in CMAQ in each grid cell gives the total nitrate response $\left(\Delta \mathrm{NO}_{3}\right)$ to $\Delta \mathrm{pH}$. Applying the eastern USA to $\Delta \mathrm{pH}=+1$ (the average $\mathrm{pH}$ impact of including NVCs in the $\mathrm{PM}_{2.5}$ calculations over the entire eastern USA) gives the $\Delta \mathrm{NO}_{3}$ distributions shown in Fig. 5 for the winter (Fig. 5a) and the summer (Fig. 5b). The predicted wintertime nitrate bias tends to be higher than in the summer, owing to the lower temperatures and higher aerosol $\mathrm{pH}$ levels present (which shift $\varepsilon_{\mathrm{NO}_{3}}$ towards higher values; Fig. 4) and the higher values of total available nitrate in the wintertime. The combination of both factors (available nitrate and high $\mathrm{pH}$ ) is necessary for appreciable quantities of nitrate to partition, but in general the locations with a $\mathrm{pH}$ of between 0.5 and 1 are the most susceptible to positive $\mathrm{pH}$ biases, since a unit increase places nitrate partitioning into the ascending part of the S-curve (Fig. 4), rapidly increasing the amount of aerosol nitrate that can form. During both seasons, areas rich in total nitrate, and a $\mathrm{pH}$ between 0.5 and 1.5 , such as the Ohio River Valley, New York, New Jersey and South Louisiana (Figs. 1, S1e, f), exhibit the largest increases in aerosol nitrate. Other locations that have low $\mathrm{pH}$ and low total nitrate such as West Virginia see minimal changes. A notable exception is North Carolina which has a higher $\mathrm{pH}$ than the aforementioned locations - mainly due to the high $\mathrm{NH}_{3}$ emissions from livestock - which pushes the partitioning beyond the sensitive regime, where increases in $\mathrm{pH}$ do not drive additional nitrate in the particle phase.

To investigate the potential of NVCs and sulfate reductions to induce nitrate substitution, the sensitivity of the nitrate increase, $\Delta \mathrm{NO}_{3}$, to the corresponding sulfate reduction, $\Delta \mathrm{SO}_{4}$, was quantified for the eastern USA, both when NVCs are included in the calculations and when they were not (Fig. 6). Over the decade, nitrate has seen increases in the eastern USA (Fig. S11) ranging from 0.5 to $2.5 \mu \mathrm{g} \mathrm{m}^{-3}$, and NVCs can have a profound impact on how these increases are distributed across the domain (Fig. S11a, b). In the presence of NVCs (Fig. 6a), there is a $1 \mu \mathrm{g} \mathrm{m}^{-3}$ increase in nitrate for a sulfate reduction of the same value over the 

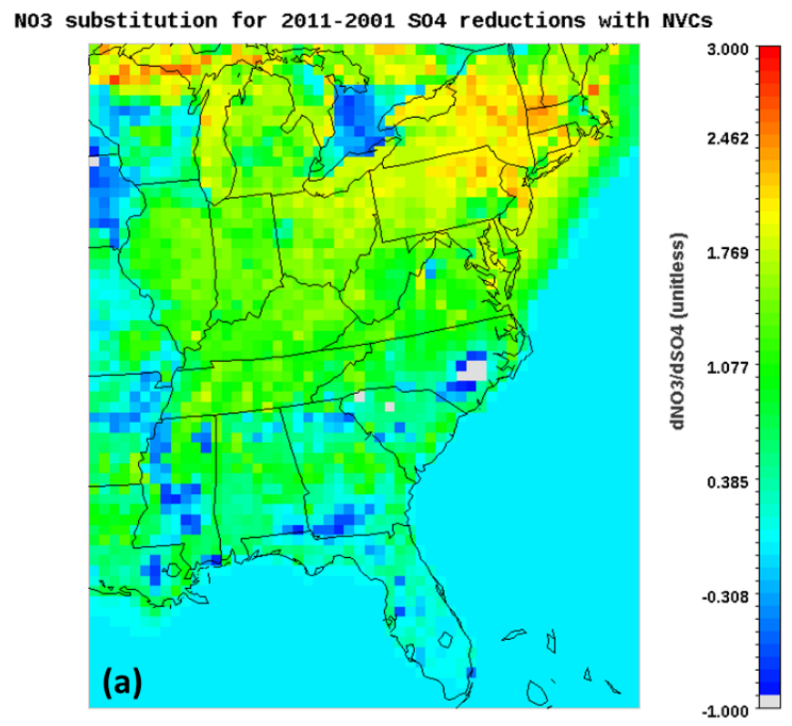

N03 substitution for 2011-2001 S04 reductions without NVCs
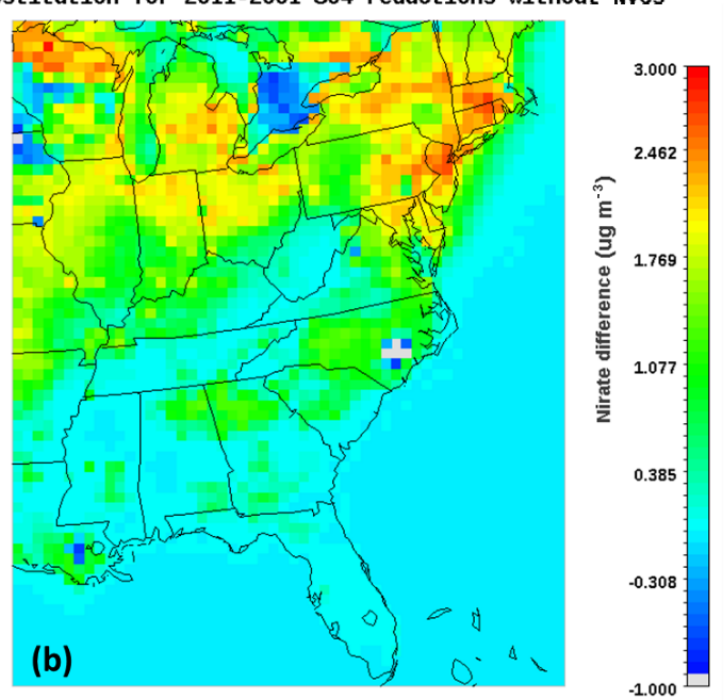

Figure 6. CMAQ predicted nitrate substitution $\left(\frac{\mathrm{NO}_{3}^{2011}-\mathrm{NO}_{3}^{2001}}{\mathrm{SO}_{4}^{2001}-\mathrm{SO}_{4}^{2011}}\right)$ over the decade, when NVCs are accounted for (a), and when they are removed from the thermodynamic calculations $(\mathbf{b})$.

eastern USA. For this case, substitution is predicted across the entire eastern USA, with only a few grid cells in southern Georgia, Mississippi and North Carolina exhibiting the opposite trend (nitrate reduction), attributed to the formation of insoluble $\mathrm{CaSO}_{4}$, which reduces the availability of aerosol water, and in turn inhibits the formation of $\mathrm{NO}_{3}$ with the co-condensation of $\mathrm{NH}_{3}$. When NVCs are removed (Fig. 6b), the corresponding nitrate increase is much less (0$0.2 \mu \mathrm{g} \mathrm{m}^{-3}$ per $1 \mu \mathrm{g} \mathrm{m}^{-3}$ of sulfate), especially in the eastern USA, while substitution is still predicted in the northern parts of the domain, such as Ohio, Indiana and Michigan. The aforementioned areas tend to have higher seasonal $\mathrm{pH}$ values than the SE USA (Fig. 1), and the removal of NVCs reduces the $\mathrm{pH}$ to values at which nitrate partitioning is more sensitive to small $\mathrm{pH}$ perturbations (Fig. 4), leading to a higher predicted sensitivity to sulfate reductions. This analysis suggests that nitrate substitution is of a much smaller magnitude than expected (West et al., 1999; Heald et al., 2012; Bauer et al., 2007; Bellouin et al., 2011; Li et al., 2014; Goto et al., 2016; Vayenas et al., 2005; Karydis et al., 2016) and heavily impacted by $\mathrm{pH}$ biases introduced by NVCs.

Given the importance of aerosol acidity for almost any aerosol-related process and impact, it is imperative that aerosol studies evaluate acidity inferred from thermodynamic analysis of ambient data as presented here. We demonstrate that, in the case of nitrate substitution, the distribution of nonvolatile cations over particle size can have a profound impact on model behavior and requires better constraints from emissions to observations (or at least appropriate sensitivity studies, such as those carried out here, to unravel the potential impact of nonvolatile cations). Under- standing aerosol $\mathrm{pH}$ and the drivers thereof is a powerful tool for evaluating model performance that has never been used before. Usage of molar ratios, ion balances and other conceptual models of aerosol acidity (Hennigan et al., 2015; Wang et al., 2016; Silvern et al., 2017) provide limited insights into aerosol $\mathrm{pH}$ and should be strongly avoided to limit incorrect conclusions.

Data availability. Data are provided with the Supplement. Raw data from the model runs can be obtained upon request.

Supplement. The supplement related to this article is available online at: https://doi.org/10.5194/acp-18-12765-2018-supplement.

Author contributions. AN and PV conceived the work; PV carried out the simulations; AN, PV, RW, AR contributed to the analysis and PV and AN wrote the manuscript. All authors commented on the manuscript.

Competing interests. The authors declare that they have no conflict of interest.

Disclaimer. This work was funded, in part, by the U.S. Environmental Protection Agency under grant RD834799. Its contents are solely the responsibility of the grantee and do not necessarily represent the official views of the US EPA. Further, the US EPA does not endorse the purchase of any commercial products or services mentioned in the publication. 
Acknowledgements. We acknowledge support from the Phillips 66 company, an EPA STAR grant and the European Research Council Consolidator grant 726165 - PyroTRACH. Observational data were provided by Atmospheric Research Associates.

Edited by: Veli-Matti Kerminen

Reviewed by: two anonymous referees

\section{References}

Air Pollutant Emissions Trends Data: https://www.epa.gov/ air-emissions-inventories/air-pollutant-emissions-trends-data, last access: 28 October 2017.

Bauer, S. E., Koch, D., Unger, N., Metzger, S. M., Shindell, D. T., and Streets, D. G.: Nitrate aerosols today and in 2030: a global simulation including aerosols and tropospheric ozone, Atmos. Chem. Phys., 7, 5043-5059, https://doi.org/10.5194/acp-7-50432007, 2007.

Bellouin, N., Rae, J., Jones, A., Johnson, C., Haywood, J., and Boucher, O.: Aerosol forcing in the Climate Model Intercomparison Project (CMIP5) simulations by HadGEM2-ES and the role of ammonium nitrate, J. Geophys. Res., 116, D20206, https://doi.org/10.1029/2011JD016074, 2011.

Blanchard, C. L., Hidy, G. M., Tanenbaum, S., Edgerton, E. S., and Hartsell, B. E.: The Southeastern Aerosol Research and Characterization (SEARCH) study: Temporal trends in gas and PM concentrations and composition, 1999-2010, J. Air Waste Manage., 63, 247-259, 2013a.

Blanchard, C. L., Hidy, G. M., Tanenbaum, S., Edgerton, E. S., and Hartsell, B. E.: The Southeastern Aerosol Research and Characterization (SEARCH) study: Spatial variations and chemical climatology, 1999-2010, J. Air Waste Manage., 63, 260-275, 2013 b.

Bougiatioti, A., Nikolaou, P., Stavroulas, I., Kouvarakis, G., Weber, R., Nenes, A., Kanakidou, M., and Mihalopoulos, N.: Particle water and $\mathrm{pH}$ in the eastern Mediterranean: source variability and implications for nutrient availability, Atmos. Chem. Phys., 16, 4579-4591, https://doi.org/10.5194/acp-16-4579-2016, 2016.

Byun, D. W. and Schere, K. L.: Review of the governing equations, computational algorithms, and other components of the Models3 Community Multiscale Air Quality (CMAQ) Modeling System, Appl. Mech. Rev., 59, 51-77, 2006.

Clegg, S. L., Pitzer, K. S., and Brimblecombe, P., Thermodynamics of multicomponent, miscible, ionic solutions. II. Mixtures including unsymmetrical electrolytes, J. Phys. Chem., 96, 94709479, https://doi.org/10.1021/j100202a074, 1992.

Eddingsaas, N. C, VanderVelde, D. G., and Wennberg, P. O.: Kinetics and Products of the Acid-Catalyzed Ring-Opening of Atmospherically Relevant Butyl Epoxy Alcohols, J. Phys. Chem. A, 114, 8106-8113, https://doi.org/10.1021/jp103907c, 2010.

Fang, T., Guo, H., Zeng, L., Verma, V., Nenes, A., and Weber, R. J.: Highly acidic ambient particles, soluble metals and oxidative potential: A link between sulfate and aerosol toxicity, Environ. Sci. Technol., 51, 2611-2620, https://doi.org/10.1021/acs.est.6b06151, 2017.

Fisher, J. A., Jacob, D. J., Wang, Q., Bahreini, R., Carouge, C. C., Cubison, M. J., Dibb, J. E., Diehl, T., Jimenez, J. L., Leibensperger, E. M., Lu, Z., Meinders, M. B. J., Pye, H. O.
T., Quinn, P. K., Sharma, S., Streets, D. G., van Donkelaar, A., and Yantosca, R. M.: Sources, distribution, and acidity of sulfateammonium aerosol in the Arctic in winter-spring, Atmos. Environ., 45, 7301-7318, 2011.

Fountoukis, C. and Nenes, A.: ISORROPIA II: a computationally efficient thermodynamic equilibrium model for $\mathrm{K}^{+}$ $\mathrm{Ca}^{2+}-\mathrm{Mg}^{2+}-\mathrm{NH}_{4}^{+}-\mathrm{Na}^{+}-\mathrm{SO}_{4}^{2-}-\mathrm{NO}_{3}^{-}-\mathrm{Cl}^{-}-\mathrm{H}_{2} \mathrm{O}$ aerosols, Atmos. Chem. Phys., 7, 4639-4659, https://doi.org/10.5194/acp-74639-2007, 2007.

Friese, E. and Ebel, A.: Temperature dependent thermodynamic model of the system $\mathrm{H}^{+}-\mathrm{NH}_{4}^{+}-\mathrm{Na}^{+}-\mathrm{SO}_{4}^{2-}$ $\mathrm{NO}_{3}^{-}-\mathrm{Cl}^{-}-\mathrm{H}_{2} \mathrm{O}$, J. Phys. Chem. A, 114, 11595-11631, https://doi.org/10.1021/jp101041j, 2010.

Ghio, A. J., Carraway, M. S., and Madden, M. C. Composition of air pollution particles and oxidative stress in cells, tissues, and living systems, J. Toxicol. Env. Heal. B, 15, 1-21, 2012.

Goto, D., Ueda, K., Ng, C. F. S., Takami, A., Ariga, T., Matsuhashi, K., and Nakajima, T.: Estimation of excess mortality due to longterm exposure to $\mathrm{PM}_{2.5}$ in Japan using a high-resolution model for present and future scenarios, Atmos. Environ., 140, 320-332, https://doi.org/10.1016/j.atmosenv.2016.06.015, 2016.

Guo, H., Xu, L., Bougiatioti, A., Cerully, K. M., Capps, S. L., Hite Jr., J. R., Carlton, A. G., Lee, S.-H., Bergin, M. H., Ng, N. L., Nenes, A., and Weber, R. J.: Fine-particle water and $\mathrm{pH}$ in the southeastern United States, Atmos. Chem. Phys., 15, 5211-5228, https://doi.org/10.5194/acp-15-5211-2015, 2015.

Guo, H., Sullivan, A. P., Campuzano-Jost, P., Schroder, J. C., LopezHilfiger, F. D., Dibb, J. E., Jimenez, J. L., Thornton, J. A., Brown, S. S., Nenes, A., and Weber, R. J.: Fine particle pH and the partitioning of nitric acid during winter in the northeastern United States, J. Geophys. Res., 121, 10355-10376, https://doi.org/10.1002/2016JD025311, 2016.

Guo, H., Nenes, A., and Weber, R. J.: The underappreciated role of nonvolatile cations on aerosol ammonium-sulfate molar ratios, Atmos. Chem. Phys. Discuss., https://doi.org/10.5194/acp-2017737, in review, 2017a.

Guo, H., Liu, J., Froyd, K. D., Roberts, J. M., Veres, P. R., Hayes, P. L., Jimenez, J. L., Nenes, A., and Weber, R. J.: Fine particle $\mathrm{pH}$ and gas-particle phase partitioning of inorganic species in Pasadena, California, during the 2010 CalNex campaign, Atmos. Chem. Phys., 17, 5703-5719, https://doi.org/10.5194/acp17-5703-2017, 2017b.

Guo, H., Weber, R. J., and Nenes, A.: High levels of ammonia do not raise fine particle $\mathrm{pH}$ sufficiently to yield nitrogen oxide-dominated sulfate production, Sci. Rep., 7, 12109, https://doi.org/10.1038/s41598-017-11704-0, 2017c.

Hand, J. L., Schichtel, B. A., Malm, W. C., and Pitchford, M. L.: Particulate sulfate ion concentration and $\mathrm{SO}_{2}$ emission trends in the United States from the early 1990s through 2010, Atmos. Chem. Phys., 12, 10353-10365, https://doi.org/10.5194/acp-1210353-2012, 2012.

Heald, C. L., Collett Jr., J. L., Lee, T., Benedict, K. B., Schwandner, F. M., Li, Y., Clarisse, L., Hurtmans, D. R., Van Damme, M., Clerbaux, C., Coheur, P.-F., Philip, S., Martin, R. V., and Pye, H. O. T.: Atmospheric ammonia and particulate inorganic nitrogen over the United States, Atmos. Chem. Phys., 12, 10295-10312, https://doi.org/10.5194/acp-12-10295-2012, 2012.

Henneman, L. R. F., Liu, C., Hu, Y., Mulholland, J. A., and Russell, A. G.: Air quality modeling for accountability research: Op- 
erational, dynamic, and diagnostic evaluation, Atmos. Environ., 166, 551-565, 2017.

Hennigan, C. J., Izumi, J., Sullivan, A. P., Weber, R. J., and Nenes, A.: A critical evaluation of proxy methods used to estimate the acidity of atmospheric particles, Atmos. Chem. Phys., 15, 27752790, https://doi.org/10.5194/acp-15-2775-2015, 2015.

Karydis, V. A., Tsimpidi, A. P., Pozzer, A., Astitha, M., and Lelieveld, J.: Effects of mineral dust on global atmospheric nitrate concentrations, Atmos. Chem. Phys., 16, 1491-1509, https://doi.org/10.5194/acp-16-1491-2016, 2016.

Kim, P. S., Jacob, D. J., Fisher, J. A., Travis, K., Yu, K., Zhu, L., Yantosca, R. M., Sulprizio, M. P., Jimenez, J. L., CampuzanoJost, P., Froyd, K. D., Liao, J., Hair, J. W., Fenn, M. A., Butler, C. F., Wagner, N. L., Gordon, T. D., Welti, A., Wennberg, P. O., Crounse, J. D., St. Clair, J. M., Teng, A. P., Millet, D. B., Schwarz, J. P., Markovic, M. Z., and Perring, A. E.: Sources, seasonality, and trends of southeast US aerosol: an integrated analysis of surface, aircraft, and satellite observations with the GEOS-Chem chemical transport model, Atmos. Chem. Phys., 15, 10411-10433, https://doi.org/10.5194/acp-15-104112015, 2015.

Laskin, A., Moffet, R. C., Gilles, M. K., Fast, J. D., Zaveri, R. A., Wang, B. B., Nigge, P., and Shutthanandan, J.: Tropospheric chemistry of internally mixed sea salt and organic particles: Surprising reactivity of $\mathrm{NaCl}$ with weak organic acids, J. Geophys. Res.-Atmos., 117, D017743, https://doi.org/10.1029/2012JD017743, 2012.

Li, J., Wang, W.-C., Liao, H., and Chang, W.: Past and future direct radiative forcing of nitrate aerosol in East Asia, Theor. Appl. Climatol., 121, 1-14, https://doi.org/10.1007/s00704-014-1249$1,2014$.

Li, W., Xu, L., Liu, X., Zhang, J., Lin, Y., Yao, X., Gao, H., Zhang, D., Chen, J., Wang, W., Harrison, R., Zhang, X., Shao, L., Fu, P., Nenes, A., and Shi, Z.: Air pollution-aerosol interactions produce more bioavailable iron for ocean ecosystems, Science Advances, 3, e1601749, https://doi.org/10.1126/sciadv.1601749, 2017.

Liu, M., Song, Y., Zhou, T., Xu, Z., Yan, C., Zheng, M., Wu, Z., $\mathrm{Hu}, \mathrm{M}$., Wu, Y., and Zhu, T.: Fine particle $\mathrm{pH}$ during severe haze episodes in northern China, Geophys. Res. Lett., 44, 5213-5221, https://doi.org/10.1002/2017GL073210, 2017.

Liu, Y., Wu, Z., Wang, Y., Xiao, Y., Gu, F., Zheng, J., Tan, T, Shang, D., Wu, Y., Zeng, L., Hu, M., Bateman, A. P., and Martin, S. T.: Submicrometer Particles Are in the Liquid State during Heavy Haze Episodes in the Urban Atmosphere of Beijing, China, Environ. Sci. Tech. Let., 4, 427-432, https://doi.org/10.1021/acs.estlett.7b00352, 2017.

Meskhidze, N., Chameides, W. L., Nenes, A., and Chen, G.: Iron mobilization in mineral dust: can anthropogenic $\mathrm{SO}_{2}$ emissions affect ocean productivity?, Geophys. Res. Lett., 30, 2085, https://doi.org/10.1029/2003GL018035, 2003.

Park, R. J., Jacob, D. J., Kumar, N., and Yantosca, R. N.: Regional visibility statistics in the United States: Natural and transboundary pollution influences, and implications for the regional haze rule, Atmos. Environ., 40, 5405-5423, https://doi.org/10.1016/j.atmosenv.2006.04.059, 2006.

Pinder, R. W., Adams, P. J., and Pandis, S. N.: Ammonia emission controls as a cost-effective strategy for reducing atmospheric par- ticulate matter in the eastern United States, Environ. Sci. Technol., 41, 380-386, 2007.

Pinder, R. W., Gilliland, A. B., and Dennis, R. L.: Environmental impact of atmospheric $\mathrm{NH}_{3}$ emissions under present and future conditions in the eastern United States, Geophys. Res. Lett., 35, L12808, https://doi.org/10.1029/2008GL033732, 2008.

Pye, H. O. T., Liao, H., Wu, S., Mickley, L. J., Jacob, D. J., Henze, D. K., and Seinfeld, J. H.: Effect of changes in climate and emissions on future sulfate-nitrate-ammonium aerosol levels in the United States, J. Geophys. Res., 114, D01205, https://doi.org/10.1029/2008JD010701, 2009.

Pye, H. O. T., Pinder, R. W., Piletic, I. R., Xie, Y., Capps, S. L., Lin, Y.-H., Surratt, J. D., Zhang, Z., Gold, A., Luecken, D. J., Hutzell, W. T., Jaoui, M., Offenberg, J. H., Kleindienst, T. E., Lewandowski, M., and Edney, E. O.: Epoxide Pathways Improve Model Predictions of Isoprene Markers and Reveal Key Role of Acidity in Aerosol Formation, Environ. Sci. Technol., 47, 11056-11064, 2013.

Pye, H. O. T., Zuend, A., Fry, J. L., Isaacman-VanWertz, G., Capps, S. L., Appel, K. W., Foroutan, H., Xu, L., Ng, N. L., and Goldstein, A. H.: Coupling of organic and inorganic aerosol systems and the effect on gas-particle partitioning in the southeastern US, Atmos. Chem. Phys., 18, 357-370, https://doi.org/10.5194/acp18-357-2018, 2018.

Saylor, R., Myles, L., Sibble, D., Caldwell, J., and Xing, J.: Recent trends in gas-phase ammonia and $\mathrm{PM}_{2.5}$ ammonium in the southeast United States, J. Air Waste Manage., 65, 347-357, https://doi.org/10.1080/10962247.2014.992554, 2015.

Silvern, R. F., Jacob, D. J., Kim, P. S., Marais, E. A., Turner, J. R., Campuzano-Jost, P., and Jimenez, J. L.: Inconsistency of ammonium-sulfate aerosol ratios with thermodynamic models in the eastern US: a possible role of organic aerosol, Atmos. Chem. Phys., 17, 5107-5118, https://doi.org/10.5194/acp17-5107-2017, 2017.

Song, S., Gao, M., Xu, W., Shao, J., Shi, G., Wang, S., Wang, Y., Sun, Y., and McElroy, M. B.: Fine-particle pH for Beijing winter haze as inferred from different thermodynamic equilibrium models, Atmos. Chem. Phys., 18, 7423-7438, https://doi.org/10.5194/acp-18-7423-2018, 2018.

Surratt, J. D., Chan, A. W. H., Eddingsaas, N. C., Chan, M., Loza, C. L., Kwan, A. J., Hersey, S. P., Flagan, R. C., Wennberg, P. O., and Seinfeld, J. H.: Reactive intermediates revealed in secondary organic aerosol formation from isoprene, P. Natl. Acad. Sci. USA, 107, 6640-6645, https://doi.org/10.1073/pnas.0911114107, 2010.

Tsimpidi, A. P., Karydis, V. A., and Pandis, S. N.: Response of inorganic fine particlulate matter to emission changes of sulfur dioxide and ammonia: the eastern United States as a case study, J. Air Waste Manage., 57, 1489-1498, 2007.

Vayenas, D. V., Takahama, S., Davidson, C. I., and Pandis, S. N.: Simulation of the thermodynamics and removal processes in the sulfate-ammonia-nitric acid system during winter: Implications for $\mathrm{PM}_{2.5}$ control strategies, J. Geophys. Res., 110, D07S14, https://doi.org/10.1029/2004JD005038, 2005.

Wang, G., Zhang, R., Gomez, M. E., Yang, L., Levy Zamora, M., Hu, M., Lin, Y., Peng, J., Guo, S., Meng, J., Li, J., Cheng, C., Hu, T., Ren, Y., Wang, Y., Gao, J., Cao, J., An, Z., Zhou, W., Li, G., Wang, J., Tian, P., Marrero-Ortiz, W., Secrest, J., Du, Z., Zheng, J., Shang, D., Zeng, L., Shao, M., Wang, W., Huang, Y., 
Wang, Y., Zhu, Y., Li, Y., Hu, J., Pan, B., Cai, L., Cheng, Y., Ji, Y., Zhang, F., Rosenfeld, D., Liss, P. S., Duce, R. A., Kolb, C. E., and Molina, M. J.: Persistent sulfate formation from London Fog to Chinese haze, P. Natl. Acad. Sci. USA, 113, 13630-13635, https://doi.org/10.1073/pnas.1616540113, 2016.

Weber, R. J., Guo, H., Russell, A. G., and Nenes, A.: High aerosol acidity despite declining atmospheric sulfate concentrations over the past 15 years, Nature Geosci., 9, 282-286, https://doi.org/10.1038/ngeo2665, 2016.

West, J. J., Ansari, A. S., and Pandis, S. N.: Marginal PM2.5: nonlinear aerosol mass response to sulfate reductions in the eastern United States, J. Air Waste Manage., 49, 1415-1424, 1999.
Wexler, A. S. and Clegg, S. L.: Atmospheric aerosol models for systems including the ions $\mathrm{H}^{+}, \mathrm{NH}_{4}^{+}, \mathrm{Na}^{+}, \mathrm{SO}_{4}^{2-}, \mathrm{NO}_{3}^{-}, \mathrm{Cl}^{-}$, $\mathrm{Br}^{-}$, and $\mathrm{H}_{2} \mathrm{O}$, J. Geophys. Res., 107, ACH 14-1-ACH 14-14, https://doi.org/10.1029/2001JD000451, 2002.

Xu, L., Guo, H., Boyd, C., Klein, M., Bougiatioti, A., Cerully, K., Hite, J., Isaacman-VanWertz, G., Kreisberg, N. M., Knote, C., Olson, K., Koss, A., Goldstein, A., Hering, S. V., de Gouw, J., Baumann, K., Lee, S. H., Nenes, A., Weber, R. J., and Ng, N. L.: Effects of anthropogenic emissions on aerosol formation from isoprene and monoterpenes in the southeastern United States, P. Natl. Acad. Sci. USA, 112, 37-42, 2015. 